\title{
The Urgence of Disaster Applications in The Era of Community 5.0
}

\author{
Imran Kahar \\ Universitas Padjadjaran (email: imrankahar2@gmail.com)
}

\begin{abstract}
People have been familiar with applications since the introduction of computers as a tool in completing work, whether in offices, companies and other businesses, where applications are now not a rare item because almost all people have smartphones. The Inarisk Disaster Application and BMKG Info that have been issued by BNPB and BMKG is an application that can be accessed by the general public to find out the possible places where disasters will occur around us, both natural and non-natural disasters. Indonesia is one of the countries that is very prone to disasters where Indonesia has several tectonic plates and is also traversed by the ring of fire zone which is very susceptible to various kinds of disasters so that a breakthrough is needed in making applications that can be connected and accessible to the public, not only those who have smartphones. live in urban areas but people live in remote areas. The government's efforts in realizing a more comprehensive disaster application need to be realized immediately because society is currently moving towards society 5.0. where all work and activities are supported by application-based technology, in addition to the existence of disaster applications, it means that the community and government can carry out early detection and prevention of possible disasters that will occur.
\end{abstract}

\section{Keywords:}

disaster applications; government and society 5.0

\section{Introduction}

Indonesia as one of the rich countries with abundant natural resources that we cannot necessarily find in other countries so that as Indonesian citizens we should be grateful for it. But on the other hand, apart from abundant natural resources, Indonesia also has several disasters, both natural and non-natural. the existence of several tectonic plates and traversed by the ring of fire which at any time can move and emit fire so that the Indonesian people must be more careful when traveling in other words, first seek accurate information about when and where a disaster will occur.

Natural and non-natural disasters such as earthquakes, landslides, volcanic eruptions and forest fires have become news that we often see and hear through electronic and print media, but in this digital era, we also cannot fully know when and where the disaster will 
occur. will occur so that a disaster application is needed that can be a liaison to find out the possibility of a disaster.

Currently, in the digitalization era, several disaster applications can be found that are easily and accessible via smartphones or news from other electronic media. Indonesia currently has two disaster applications, namely the Inarisk application and BMKG info from the two disaster applications, of course it cannot be said to be perfect. However, the application can be a means of finding initial information related to disasters that will occur in the future so that they can make wise decisions before carrying out a trip or activity carried out outside the home or in other places that are not yet known whether the area is prone to disasters or not.

The Inarisk application was developed by the National Disaster Management Agency (BNPB) where this application system can detect potential disasters and can be accessed by the Regional Disaster Management Agency (BPBD) and the wider community. Inarisk is a web-based system and application that displays disaster risks in Indonesia. The information includes, disaster hazard information and what actions the community should take when a disaster occurs. For example, before and after a flood occurs, the community can know what actions to take. Not only that, Inarisk also utilizes basic information, such as base maps from the Geospatial Information Agency (BIG), hazard maps from data trustees, such as flood maps from the Ministry of Public Works and Public Housing (PUPR), landslide and volcanic maps from the Meteorological Agency. So, Inarisk combines three pieces of information, such as one hazard information, vulnerability information and capacity information whether the local government already has a disaster map or not, whether the local government has a disaster regulation or not.

BMKG Info is an application that has been launched by BMKG. Where there are several features provided such as earthquake notifications, weather early warnings, and actual information about BMKG. Users can get information about weather forecasts based on location. including earthquake information, although currently only earthquakes with a magnitude above 5 on the Richter scale will appear as notifications, equipped with the distance from the epicentrum to the user's location.

The existing applications, both InaRisk and BMKG Info, are applications that are very much needed by the community in the era of digitalization of society 5.0. is a must or must 
have it because Indonesia is a country that has many disaster-prone areas, both natural and non-natural disasters.

\section{Methods}

The method that the author uses is a qualitative method by collecting data and looking at existing reports both from print and electronic media as well as statements from several resource persons or experts so that they can provide additional data that can be included in this paper. According to Sugiyono in his book entitled Understanding Qualitative Research, that qualitative research methods are "Qualitative research is a process of inquiry about understanding based on separate methodological traditions; clear examination that explores social or human problems. The author constructs a complex, holistic picture, examines words, reports and details the views of native speakers, and conducts the study in a natural setting. (Sugiyono 2007).

\section{Results and Discussion.}

a. Inarisk application.

In the Inarisk Disaster Application, users can find out the risks of disasters that can occur in their area, such as floods, flash floods, extreme weather, extreme waves and abrasion, earthquakes, forest and land fires, droughts, volcanic eruptions, landslides, tsunamis, and multi-hazard disasters.

Districts or the number of sub-districts that use data from the Central Statistics Agency. The level of the study measured is based on several parameters, such as population, BPS data Number of houses, public facilities, critical facilities BPS data, BIG, Inarisk can also be used to determine the hazard index, vulnerability, and capacity of a type of disaster. The results will be known in the form of a digital map that is displayed in different color gradations according to the desired level of study. This map can be enlarged and reduced making it easier for users to know down to the detailed regional level. and Local Government GRDP data and local government data Land cover data KLHK and BIG In addition to knowing the study of a disaster in an area, this application also presents prevention and rescue measures that must be taken by the community if they are in an area that has a potential disaster. 
In addition to the Disaster Application at Inarisk, currently there is also a Covid-19 hazard info application that is around people using the application. ${ }^{1}$

BNPB Inarisk Application Risk Map Analysis

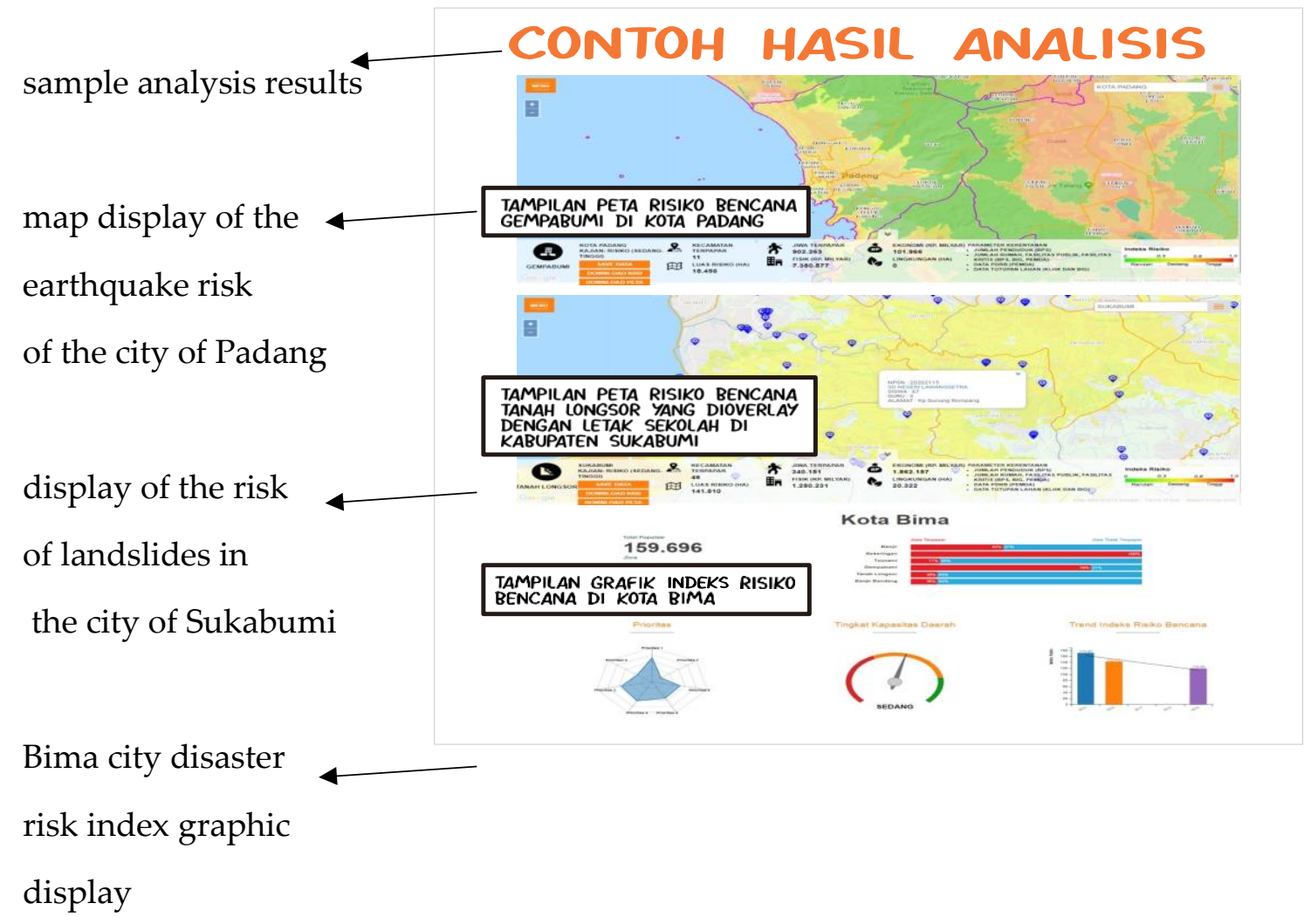

Community data using the BNPB Inarisk Aplication

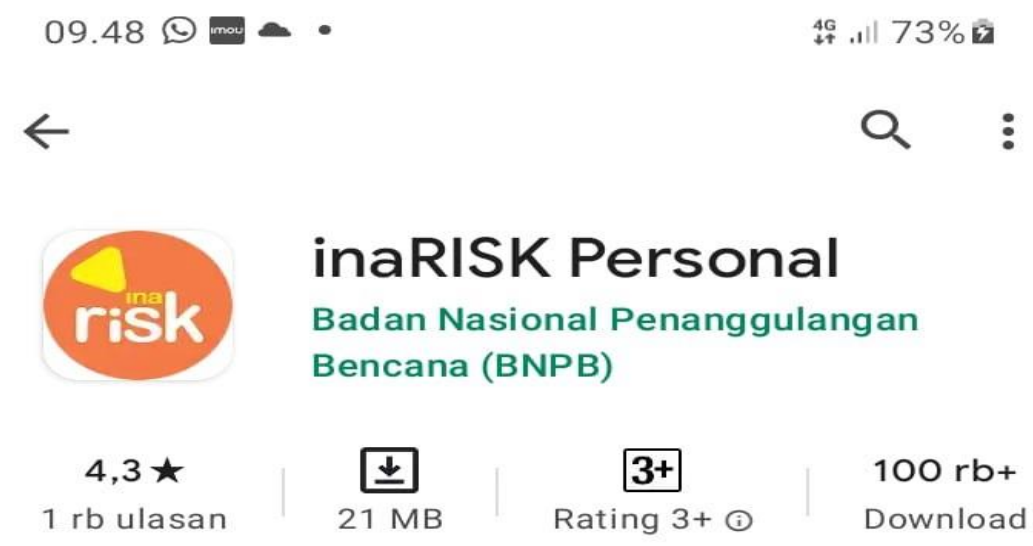

${ }^{1}$ Guide to using Inarisk Booklet.CDR version 
As for the number of Natural Disasters in Indonesia (1 January-18 June 2021), the National Disaster Management Agency (BNPB) noted, a total of 1,441 natural disasters that hit Indonesia from January 1 to June 18 2021. The most natural disasters were floods, with 599 incidents. Then a tornado with 398 events.

The Government's efforts in this case BNPB in creating and developing a Disaster application to determine the possibility of a disaster occurring are in line with several countries that have made a similar disaster application such as the United States, Japan, Netherlands and UAE. The existence of a disaster application such as Inarisk will be very useful for the Indonesian people and foreign nationals who will visit Indonesia.

From the data above, the author argues that most Indonesian people do not fully know areas that are prone to disasters, but with the existence of a disaster application made by the government, in this case BNPB, it has become a leap in the technology era. In order to be able to provide accurate information about possible disasters that can occur, the Inarisk application based on Android and Ios applications will greatly assist the government in providing disaster information to the community, both those who will carry out activities in other areas or around their homes in order to minimize the possibility of victims. both loss of life and material.

b. BMKG info application.

The BMKG info application as a means of communicating and providing information to the public is carried out through the internet network or in other words through the latest technology. The BMKG Info application is an application that can be used with an internet network on a wireless device or smartphone, Currently the need for weather information continues to increase in the face of the current uncertain weather so that BMKG as one of the institutions with an interest is called to provide the latest Android-based innovations for the community. In general, this application can help the public to get information about Indonesia's weather forecasts and early warnings of bad weather estimates of natural conditions, such as weather forecasts, air quality, climate, earthquakes, and so on related to meteorology, climatology, and geophysics.

Functionally, this application is not much different from other existing weather forecasting applications, but according to BMKG its weather information application can 
provide early weather warnings. The scale of the early warning information is not only limited to the province, but also to the sub-district level where you can find out the weather forecast in 7 days with forecasts every 3 hours per day in all sub-districts in Indonesia (BMKG, 2021).

BMKG Info Application Productivity Chart

annual report infographic. summary of the productivity of information services in the field of engineering seismology. (2016)

Infografis Laporan Tahunan

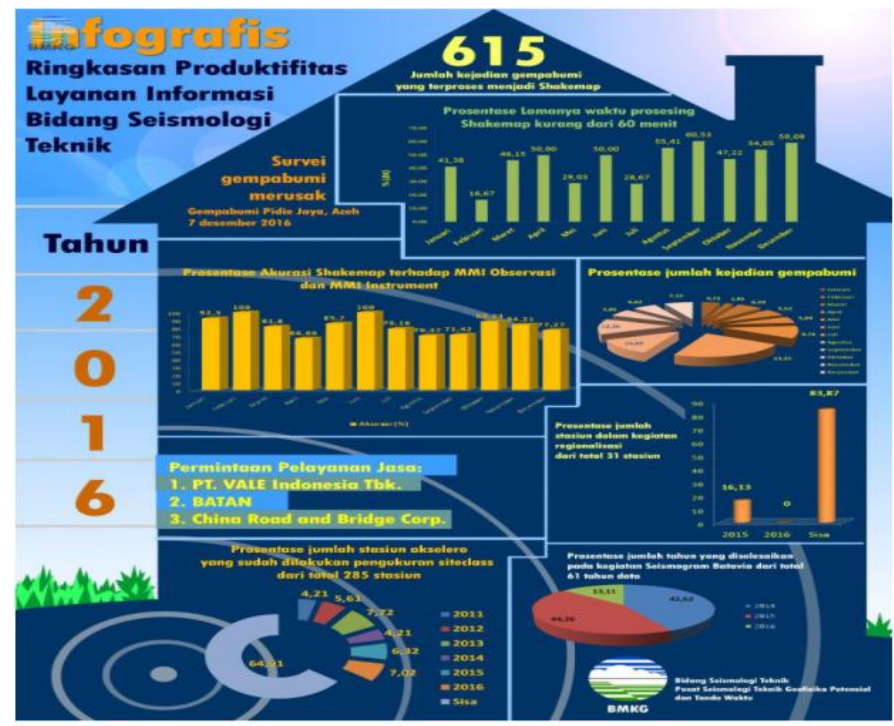

BMKG Info Application user data

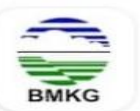

$4,6 \star$

68 rb ulasan

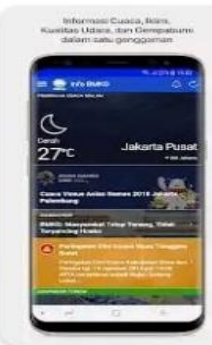

Info BMKG

Badan Meteorologi Klimatolo...

Rating $3+$ (i)

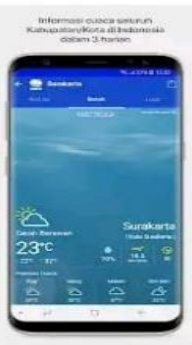

$3+$

Instal

$5 \mathrm{jt}+$

Download
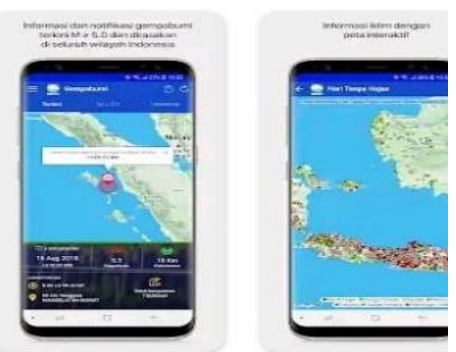

Cuaca, Iklim, dan Gempabumi Indonesia 
The BMKG Info application has won the World Meteorological Organization (WMO) International Weather Award Apps Award 2020, which is a prestigious event for application developers engaged in the world's weather.

The author is of the opinion that with the BMKG information application created by BMKG, it can be accessed easily via smartphones, but there are still people who have not been able to access the application, even though Indonesia is currently in the era of society 5.0 which prioritizes digitizing information systems. This situation can be used as an evaluation material for the government in providing accurate information related to disasters despite the various obstacles and limitations that are currently being faced.

\section{Conclusion}

All the efforts that have been made by the government by making a breakthrough by utilizing digitalization technology and information in the era of society 5.0. disaster app that At this time we need to appreciate even though there are advantages and disadvantages that need to be fixed immediately. There are two government institutions, namely BNPB and BMKG which have issued different disaster applications but the goal remains one, namely how the public gets information accurate information on the possibility of disasters that will occur in the future and how to prevent them so that the government in this case can take a measurable action against the possibility of casualties and material. But it can be seen from the data above the existing disaster application users are still very few.

For this reason, so that this disaster application is useful and can be accessed by the entire community, it is necessary to consider, namely (1) The need for the government to appoint a government agency that is more authorized according to applicable laws and regulations to issue a more complete disaster application according to the needs of the community. (2) The government needs to make a grand design that combines disaster-prone areas with areas that do not yet have an internet network. (3) The need for the government to create a rule that requires people to use disaster applications just like the protect care application required by the government if going to travel. 


\section{References}

(Sugiyono 2007). Understanding Qualitative Research, (BNPB) Indonesian Disaster Risk Book Republic of Indonesia (2008) Government Regulation No. 21 of 2008 Disaster Management Implementation

BNPB (2018) BNPB Regulation Number 07 of 2012 Guidelines for data and information management Indonesian Disaster

\section{Website}

https://inarisk.bnpb.go.id/about

https://apps.bmkg.go.id/

https://mediaindonesia.com/humaniora/369340/aplikasi-info-bmkg-menang-penghargaaninternasional

https://bahasan.id/5-aplikasi-canggih-pendeteksi-bencana alam http://jurnal.ubl.ac.id/index.php/explore/article/view/1085/1137

https//nasional.kompas.com/read/2018/08/24/20430031/mengenal-inarisk-aplikasi-untukkaji-potensi-bencana-dari-bnpb http://dhanytama.blogspot.com/2016/12/aplikasi- info-bmkg-untuk-android.html 